\title{
QUANTITATIVE ASSESSMENT OF THE INDUSTRIAL COMPOSITION IN THE COUNTRY'S REGIONS
}

\author{
Romualdas GINEVIČIUS*, Dainora GEDVILAITĖ, Andrius STASIUKYNAS \\ Department of Economics Engineering, Faculty of Business Management, \\ Vilnius Gediminas Technical University, Sauletekio al., LT 10223 Vilnius, Lithuania
}

Received 03 November 2017; accepted 24 March 2018

\begin{abstract}
To this date, insufficient number of reasoned methods for assessing the industrial composition in the country or in the region in an integrated and quantitative manner is on offer. The existing proposals are basically intended for explaining the drivers of change in the industrial composition as well as the reasons thereof. Following this analysis, the most export-oriented industries are determined. Hence, the focus is not on assessing the industrial composition of a country or a region itself in a quantitative manner, but rather the impact of the changes thereof on economic indicators, i.e. derivative measures of industrial composition. The industrial composition of a country or a region can be described through indicators that reflect three key aspects, i.e. the variety of active economic entities by their number, size and types of economic activities. The proposed methodology is suitable for assessing the industrial composition of a country's region.
\end{abstract}

Keywords: regional industry, industrial composition assessment, economic development, industry structure, industrial composition.

JEL Classification: R11.

\section{Understanding the industrial complex of a country's region as a formation}

A few methodological questions need to be answered before starting to directly examine the issue of quantitative assessment of industrial composition of a country's region. First of all, what definition suits the industrial composition of a region best, i.e. that of a structure, formation, complex, etc. It needs to be established whether the object subject to our examination, i.e. the industry of a country's region, is a system. If the industry of a country's region is a system it must meet three conditions: aggregate, interconnection and structuring.

The industry in a country's region comprises an aggregate of undertakings of different size and with different profiles of activities that is closed in terms of its space. The limits of an industrial complex are defined by the territory of the region. We can state that the condition of the aggregate has been met. To meet the second condition, there must be interconnections

\footnotetext{
*Corresponding author. E-mail: romualdas.ginevicius@vgtu.lt
} 
between the industrial entities of the region. We must be able to state, without further analysis, that this condition has not been met. Every industrial undertaking of a region is legally and economically independent; it has its own objectives of activities which are developed independently of the goals of other undertakings. Following on from the fact that there is no interconnection between the industrial undertakings of the country's region as elements of the system, it is impossible to meet the third systematic condition of structuring. Structuring the elements directs the interconnection between them towards achieving a common goal of the system, i.e. it gives the focus of functioning to the system. We can state that regional industrial undertakings located within the region are not a system because they meet only one of the three systematic conditions. Hence, we cannot talk about the structure of this complex.

\section{Existing methods for assessing industrial composition}

The industry of both the countries and the regions being the basis for their economic and social development draws much attention in the sources of literature. All this research essentially focuses not on the direct assessment of the industrial composition, but on establishing the impact on a variety of development indicators.

In this context, it is sought to establish what activities the industry focuses on, what industries are competitive in the circumstances of economic integration, what the industrial potential is, what the reasons for the changes in the industrial composition are, etc. (Kozubikova, Homolka, \& Kristalas, 2017; Brunner \& Cali, 2006; Rajnoha \& Lesníková, 2016; Capasso, Stam, \& Cefis, 2015; Hallack, 2004; Hongxia \& Guoping, 2011; Janissen, Thomson, Clark, \& Geer, 1998; Szirmai, Ruoen, \& Bai, 2005). Only certain authors seek to define the aspects reflecting industrial composition. However, this is done in a non-systematic manner (Bradbury \& Kodrycki, 2007; Carlton \& Perloff, 1994; Duman, Tozanli, Kongar, \& Gupta, 2017; Grasmik, 2015).

A proportion of research is intended for examining internal and external factors that have an impact on the industrial composition (Saboniené, 2010). The former include the following: research and development intensity; technological opportunities; advertising intensity; high and low skilled labour; trade orientation; capital intensity; increasing returns; direct network effect; labour productivity growth; value added and wage per employee.

The external factors shaping the industrial composition include the following: economic integration and business globalisation; competitive conditions; the level of competition; geographical concentration; international exchange rates; the volume and GDP growth rates; export growth and sectoral export intensity and industry growth.

The contents of both internal and external factors demonstrate that at best they facilitate the analysis of changes in the industrial composition only, whereas the industrial composition itself is left on the sidelines. However, such changes and the reasons therefor are dependent on the above.

A large proportion of research focuses on a deeper analysis of changes in the industrial composition (Bernatonyte \& Normandiene, 2009; Carlton \& Perloff, 1994; Dumčiuvienè, 2001; Janissen et al., 1998; Sabonienè, 2010). 
Janissen et al. (1998), for instance, distinguishes four key reasons, in their opinion, pertaining to the changes in the markets. These include technological and behavioural changes as well as changes resulting from the development of internal trade and global specialisation as well as from the depletion of non-renewable resources.

Authors suggest five reasons for the changes in the industrial composition (they call these structural changes): i.e. liberalisation of trade and investment; reforms in infrastructure and the overall governance of a country as well as labour market; competition and reforms in other regulatory methods and tax systems.

The goal of the analysis of such reasons for the changes in industrial composition is providing proposals for the assessment thereof (not of the industrial composition, but of its changes). One of such proposals includes determining the scope of specialisation in a country's or a region's trade that is defined as the produce exported by the industries, i.e. of the specialisation of produce to be exported. The calculations are based on the exports and imports of the goods in industrial sectors (Anderson, 1995; Balassa, 1965; Chow \& Kellman, 1993; Drysdale, 1988; Garnaut, 1989; Sheehan, 2000; Misra, 2006; Sabonienė, 2009; Snieška \& Bruneckiene, 2009; Čiučkovič, Jurlin, \& Vučkovič, 2013). The same authors acknowledge that the application of this method is cumbersome if we wish to assess the country's or the region's industry as a whole as opposed to individual industries (Saboniene, 2010). To find a way out, the level of specialisation is firstly assessed in all sectors, then the results are combined into a summarising indicator. It is obtained on the basis of the research and development expenses in different industries and demonstrates to what degree the exports of goods are concentrated in such industries which pay much attention to research and development (Sheehan \& Tikhomirova, 1996).

The fact that the proposed methodology is suitable for assessing the industrial composition of a country or a region is demonstrated by the indicators that are intended for reflecting the key industrial aspects. These include value added and wage per employee; export growth; sectoral export intensity as well as the indicator of research and development and the application thereof (Sabonienè, 2010; Tikhomirova, 1997).

All this analysis is essentially focused on assessing the revenue stream as well as value added per employee that are reliant on the existing industrial composition (Sheehan, 2000).

To summarise, it is possible to state that research intended for examining the industrial composition of a region are essentially focused on the analysis of the impact thereof on a variety of development indicators as opposed to direct assessment thereof.

\section{Proposed methodology for quantitative assessment of the industrial composition in a country's region}

It has been unambiguously agreed that economic development is the basis for the development of a country's region because it affects social (first of all, employment) and other problems being resolved (Boggia \& Cortina, 2010; Karabaga \& Berggren, 2014; Kondyli, 2010; Silva \& Ferreira-Lopes, 2014; Wu \& Tam, 2015). In turn, the basis of the economic development lies in the industry. The question arises what the composition thereof should be to maximise the contribution of the industry to the economic-social development. 
Given the significance of the industry to the economic-social development of a region, it is important to have a possibility to assess its existing composition with the help of certain indicators. This would help propose ways for improving the industrial composition in a region as well as increasing its contribution to the economic-social development of the region.

The more economic entities are active in the region, the larger the opportunities for meeting its social needs are. This, first and foremost, increases employment, exports volume as well as the competitiveness of the region at the same time. Hence, the number of economic entities in the region might be one of the indicators of the industrial composition. On the other hand, this indicator portrays only a quantitative side of the industry. The qualitative side of the industry is of equal importance to new jobs being created. How can it manifest itself? It has been stated in the literature that the most jobs are created by small and medium businesses. This implies that the second indicator for the condition of the industry in a region could be a variety of sizes of economic entities.

For the purpose of both creating new jobs and meeting other social needs of the region, not only a variety of the sizes of entities, but also of the profile of their activities is relevant because the more economic activities are developed in a region, the more residents can practice their occupation.

Therefore, three aspects that reflect the condition of the industry in a country's region become evident: the number of economic entities and a variety of their size as well as of economic activities that they pursue. They shape the area of the quantitative assessment of industrial composition in a country's region (Figure 1).

An issue of equal importance is determining the quantitative value of all aspects illustrated in Figure 1 that would turn them into criteria. In other words, the aggregate of all undertakings active in the region and the variety of their size as well as the types of economic activities need to be quantified.

The produce of any undertakings emerges as a result of interactions between people and technological equipment. The result of such interaction is the volume of output. On the one hand, dependent of the nature of economic activities, this volume is determined by the number of employees (in entities with low technological level), on the other hand, it is

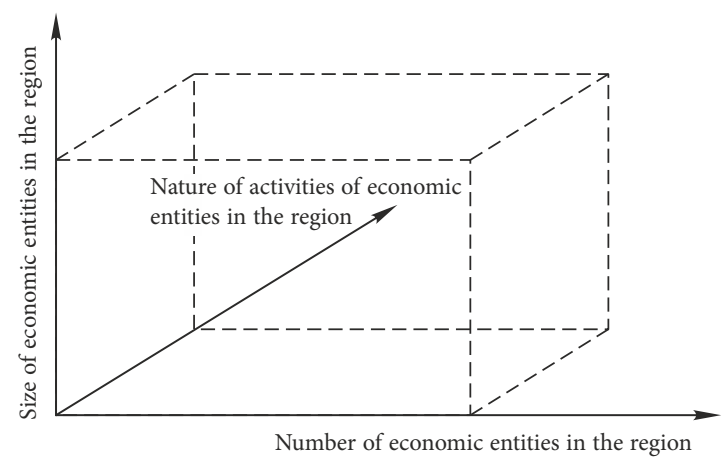

Figure 1. Area of quantitative assessment of the composition of industrial undertakings in a country's region 
determined by the level of technologies invoked (in entities with high technological level). In the light of the above, in order to obtain an objective view, the criteria that shape the area of research (number, size and variety of activities of undertakings) need to be denoted in two ways through employees and turnover, i.e. the volume of output.

To rank the regions by the composition of industrial undertakings active therein or assess the industry of an individual region, relevant information in terms of all three aspects above is required. In Lithuania, it is provided in the publication of the Statistics Lithuania "Counties of Lithuania" that is published annually (Lietuvos statistikos departamentas, 2014). Therein, the mentioned data is presented from certain angles that have to be relied upon.

It is also necessary to assess one more significant aspect. The country's regions are different in terms of both their area and population. For instance, the area of the largest region in Lithuania is over 2.2 times larger than the area of the smallest region, whereas it is 7.5 times in terms of population. This needs to be taken into consideration when determining the indicators for quantitative assessment of the industrial composition.

All of the afore-mentioned circumstances allow generating the following system of indicators of quantitative assessment of industrial composition in a country's region (Figure 2).

As seen from Figure 2, the system of indicators shows both the quantitative and the qualitative side of the industrial composition in a region.

The first one amongst the indicators of the industrial composition in a country's region, i.e. the number of economic undertakings active therein, may be assessed through two partial indicators. The first one would reflect the number of active economic undertakings per one thousand inhabitants of the region; whereas the second one is the turnover of such economic entities per one thousand inhabitants of the region.

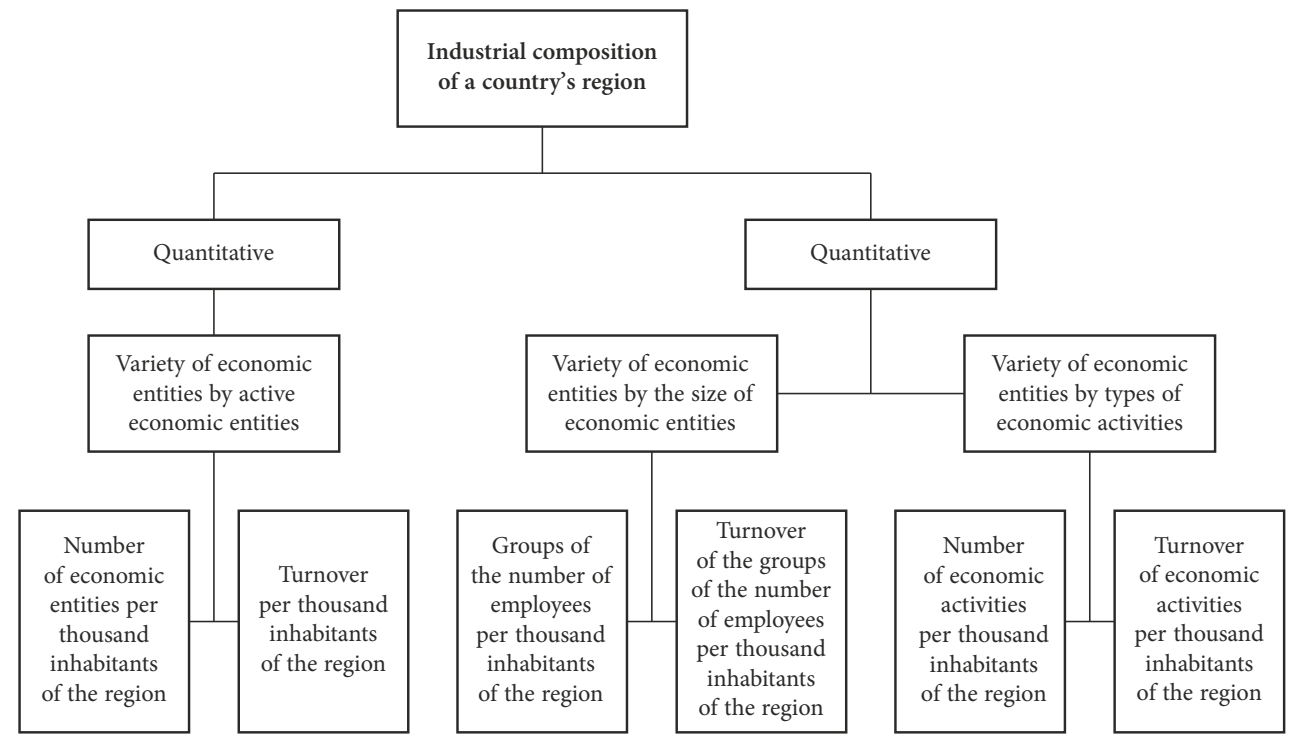

Figure 2. The system of indicators for quantitative assessment of the composition of industrial complex in a country's region 
The first partial indicator can be calculated in the following manner:

$$
S_{V S j}=\frac{N_{j}}{G_{j}},
$$

where $S_{V S j}$ is the variety of economic entities of the $j$ region of a country presented in the number of active economic entities per one thousand inhabitants of the region; $N_{j}$ is the number of economic entities active in the $j$ region of a country, in units; $G_{j}$ is the population of the $j$ region of a country, in thousands of inhabitants.

The second partial indicator can be calculated in the following manner:

$$
S_{V A j}=\frac{Q_{j}}{G_{j}},
$$

where $S_{V A j}$ is the variety of economic entities of the $j$ region of a country presented through their turnover per one thousand inhabitants of the region, in million EUR; $Q_{j}$ is the aggregate turnover of economic entities of the $j$ region of a country, in million EUR.

The variety of undertakings by their size can also be presented through two partial indicators. The first one reflects the variety of economic entities presented in the groups of the number of employees; whereas the second one is the variety of economic entities presented in the turnover of the groups of the number of employees.

The Statistics Lithuania provides for the following classification of the size of economic entities by groups of the number of employees (Table 1).

Table 1. Active economic entities by groups of the employee numbers (source: FF)

\begin{tabular}{|l|c|c|c|c|c|c|c|c|c|c|}
\hline Group No & 11 & 2 & 33 & 44 & 55 & 66 & 77 & 88 & 99 & 110 \\
\hline $\begin{array}{l}\text { Number } \\
\text { of } \\
\text { employees }\end{array}$ & $00-4$ & $55-9$ & $110-19$ & $220-49$ & $550-99$ & $1100-149$ & $1150-249$ & $2250-499$ & $5500-999$ & $\geq 1000$ \\
\hline
\end{tabular}

The first partial indicator can be determined in the following manner:

$$
S_{D S j}=\frac{\sum_{i=1}^{m}\left(f_{k j}-\bar{F}_{j}\right)^{2}}{G_{j}},
$$

where $S_{D S j}$ is the variety of economic entities of the $j$ region of the country presented in the groups of the number of employees per one thousand inhabitants of the region; $f k j$ is the total number of employees in the $k$ group of economic entities of the $j$ region of the country; is the weighted average of the number of employees in all groups of economic entities of the $j$ region of the country.

The value of shall be determined in the following manner:

$$
\overline{F_{j}}=\frac{\sum_{i-1}^{n} \bar{d}_{k} f_{k j}}{\sum_{i=1}^{n} \bar{d}_{k}}, k=\overline{1, n}
$$

where $\bar{d}_{k}$ is the mean of the $\mathrm{k}$ group of economic entities. 
Following Table 1 , the value of $\bar{d}_{k}$ shall be determined in the following manner:

$$
\bar{d}_{k}=\frac{d_{k}^{\min }+d_{k}^{\max }}{2}
$$

where $d_{k}^{\min }$ is the minimum number of employees in the k group of economic entities; $d_{k}^{\max }$ is the maximum number of employees in the $k$ group of economic entities.

The second indicator, which is identical to indicator $S_{D G j}$, may be determined in the following manner:

$$
S_{D A j}=\frac{\sum_{i=1}^{m}\left(\bar{d}_{k j}-\bar{A}_{j}\right)^{2}}{G_{j}},
$$

where $S_{D A j}$ is the variety of economic entities of the $j$ region of the country presented as the turnover of the groups of the number of employees per one thousand inhabitants of the region; $\bar{d}_{k j}$ is the turnover of the k group of economic entities of the $j$ region of the country; $\bar{A}_{j}$ is the weighted average of turnover of all groups of economic entities of the $j$ region of the country.

The value of $\bar{A}_{j}$ shall be determined in the following manner:

$$
\bar{A}_{j}=\frac{\sum_{i=1}^{n} \bar{d}_{k} a_{k j}}{\sum_{i=1}^{n} \bar{d}_{k}},
$$

where $a_{k j}$ is the aggregate turnover of the $\mathrm{k}$ group of economic entities in the $j$ region of a country.

We will also denote the variety of economic entities active in a country's region by the types of their economic activities through two partial indicators. The first one shows the variety of undertakings by the types of economic activities presented as the number of economic activities; whereas the second one is the variety thereof by the types of economic activities presented through their turnover.

The first partial indicator can be determined in the following manner:

$$
S_{E S j}=\frac{\sum_{l=1}^{p}\left(E_{e j}-\bar{E}_{j}\right)^{2}}{N_{j} G_{j}}, e=\overline{1, p},
$$

where $S_{E S j}$ is the variety of economic entities of the $j$ region of the country presented through the number of types of economic activities per one thousand inhabitants of the region; $E_{e j}$ is the number of economic entities within the economic activity $l$ active in the $j$ region of the country; $\bar{E}_{j}$ is the arithmetic average of the number of economic entities within the economic activity $l$ active in the $j$ region of the country by all types of economic activities.

The second partial indicator can be determined in the following manner:

$$
S_{E A j}=\frac{\sum_{l=1}^{m}\left(R_{e j}-\bar{R}_{j}\right)^{2}}{R_{j} G_{j}},
$$


where $S_{E A j}$ is the variety of economic entities of the $j$ region of the country by types of economic activities presented through their turnover per one thousand inhabitants of the region; $R_{e j}$ is the turnover of the economic entities engaged in the economic activity $i$ active in the $j$ region of the country; $\bar{R}_{j}$ is the arithmetic average of turnover of the economic entities active in the $j$ region of the country by all types of economic activities; $R_{j}$ is the aggregate turnover of economic entities active in the $j$ region of the country.

\section{Integrated assessment of industrial composition in a country's region}

The quantitative assessment of the industrial composition is not an end in itself. It is required for the purpose of establishing the impact that the industry has on the economic, social and environmental development of a country's region. In this sense, the integrated impact of both individual indicators of the industrial composition and their totality is of interest. It can be examined only in the presence of a summarising indicator of the industrial composition. And in order to obtain it, it is first needed to develop a system of indicators of quantitative assessment of the industrial composition in a country's region. This can be done following Figure 2 (Figure 3).

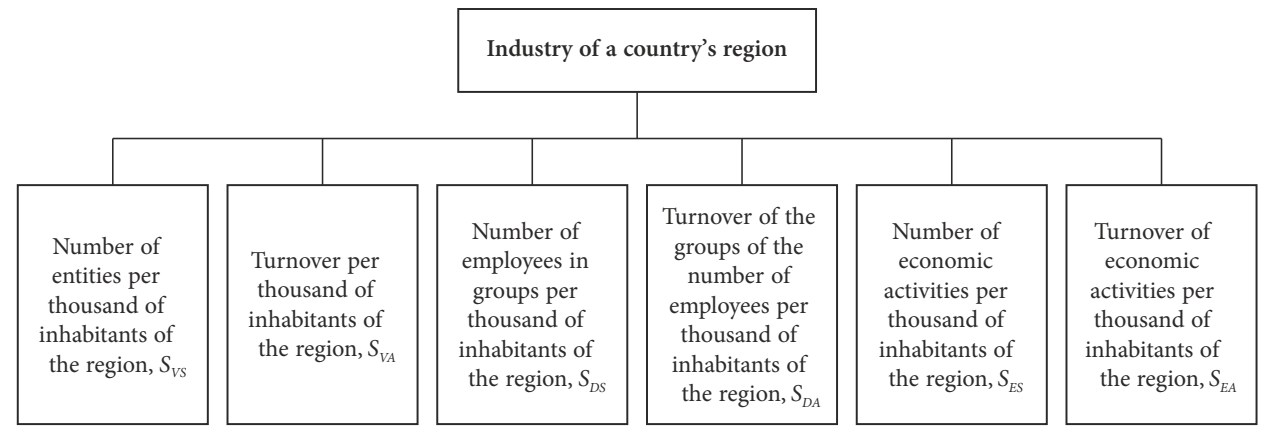

Figure 3 . The system of indicators of the industrial composition in a country's region

The industrial composition of a country's region can be assessed in a quantitative manner on the basis of the multicriteria assessment model SAW (Hwang \& Yoon, 1981):

$$
K_{j}=\sum_{i=1}^{n} w_{i} \tilde{S}_{j i}
$$

where $K_{j}$ is the indicator of integrated quantitative assessment of the industrial composition of the $j$ region of the country; $w_{i}$ is the weight of the indicator $i\left(\sum_{i=1}^{n} w_{i}=1,0\right) ; \tilde{S}_{j i}$ is the normalised value of indicator $i$ of the $j$ region of the country; $n$ is the number of indicators, $i=\overline{1, n}$.

The normalisation of the values of partial indicators is necessary to harmonise the different dimensions thereof. The method to do this depends on the objective of the quantitative 
assessment of the composition of the industrial complex in the region. If we want to rank all regions of the country by their $K_{j}$ value, the normalisation shall be carried out in the following way (Ginevičius \& Podvezko, 2008):

$$
\tilde{S}_{j i l}=\frac{S_{j i l}}{\sum_{i=1}^{n} S_{j i l}},
$$

where $\tilde{S}_{i j l}$ is the normalised value of indicator $i$ of aspect $l$ of the $j$ region of the country; $S_{j i l}$ is the non-normalised value of indicator $i$ of aspect $l$ of the $j$ region of the country; $n$ is the number of indicators.

If the objective of quantitative assessment of the composition of the industrial complex of the region is assessing the situation of an individual region, the normalisation shall be carried out in the following manner (Ginevičius et al., 2015):

$$
\tilde{q}_{i j}=\frac{S_{j i l}}{\max S_{j i}},
$$

where $\max q_{i j}$ is the maximum determined value of indicator $i$ of aspect $l$ of the $j$ region of the country (it can be the actual maximum value of the indicator subject to examination for all regions of the countries or it may be determined by experts).

In order to perform the correlation analysis of the impact of the industrial composition on the economic and social development of the region, the indicator values have to be normalised following formula (12).

It is evident from formula 10 that the weights and importance of the indicators to the phenomenon subject to examination have to be assessed. We will accept that all indicators are equal. In such event, we will obtain the value of the integrated assessment of the industrial composition sought by adding up the indicator values:

$$
K_{j}=\sum_{i=1}^{n} \tilde{S}_{j i} .
$$

We are interested in what the structural impact of the industrial composition is on the selected indicators of economic and social development of the region. Hence, we will undertake an integrated quantitative assessment of the industrial composition from the following angles (Table 2).

Based on the system of indicators presented in Ill. 3 and Formulas 1 to 9, the indicators of the industrial composition in the Lithuanian regions were established in line with the structure of Table 2 (Table 3). They have been calculated on the basis of the data provided by the Statistics Lithuania (Lietuvos statistikos departamentas, 2014).

Based Table 3 and Formulas 12 to 13, the values of the integrated assessment of the industrial composition in the Lithuanian regions $K_{j}$ were established in line with the structure presented in Table 2. The results of the calculations have been provided in Table 4.

Now that the integrated quantitative assessment of the industrial composition in the regions of the country has been completed, we can move on to the final stage of the analysis. 
Table 2. The structure of integrated quantitative assessment of the industrial composition in Lithuanian regions

\begin{tabular}{|c|l|c|}
\hline No & \multicolumn{1}{|c|}{ Name of integrated quantitative assessment } & \multicolumn{1}{|c|}{ Assessment formula } \\
\hline 1 & $\begin{array}{l}\text { Overall integrated quantitative assessment of } \\
\text { industrial composition in a region (all six indicators } \\
\text { of the industrial composition are to be assessed), } \\
S_{V D E}\end{array}$ & $S_{V D E}=\tilde{S}_{V S}+\tilde{S}_{V A}+\tilde{S}_{D S}+\tilde{S}_{D A}+\tilde{S}_{E S}+\tilde{S}_{E A}$ \\
\hline 2 & $\begin{array}{l}\text { Integrated quantitative assessment of the variety of } \\
\text { undertakings by the economic entities active in the } \\
\text { region, } S_{V S A}\end{array}$ & $S_{V S A}=\tilde{S}_{V S}+\tilde{S}_{V A}$ \\
\hline 3 & $\begin{array}{l}\text { Integrated quantitative assessment of the variety of } \\
\text { undertakings by their size, } S_{D S A}\end{array}$ & $S_{D S A}=\tilde{S}_{D S}+\tilde{S}_{D A}$ \\
\hline 4 & $\begin{array}{l}\text { Integrated quantitative assessment of the variety of } \\
\text { undertakings by types of economic activities, } S_{E S A}\end{array}$ & $S_{E S A}=\tilde{S}_{E S}+\tilde{S}_{E A}$ \\
\hline 5 & $\begin{array}{l}\text { Integrated quantitative assessment of the variety of } \\
\text { undertakings presented as the number of economic } \\
\text { entities active in the region }\left(S_{V S}\right) \text {, groups of the } \\
\text { number of employees }\left(S_{D S}\right) \text { and the number of types } \\
\text { of economic activities }\left(S_{E S}\right), S_{V D E S}\end{array}$ & $S_{V D E S}=\tilde{S}_{V S}+\tilde{S}_{D S}+\tilde{S}_{E S}$ \\
\hline 6 & $\begin{array}{l}\text { Integrated quantitative assessment of the variety } \\
\text { of undertakings presented through the turnover } \\
\text { of economic entities active in the region }\left(S_{S A}\right), \\
\text { turnover of the groups of the number of employees } \\
\left(S_{D A}\right) \text { and turnover of economic activities }\left(S_{E A}\right), \\
S_{V D E A}\end{array}$ & $S_{V D E A}=\tilde{S}_{V A}+\tilde{S}_{D A}+\tilde{S}_{E A}$ \\
\hline
\end{tabular}

Table 3. Indicators of industrial composition in Lithuanian regions, 2013

\begin{tabular}{|c|l|c|c|c|c|c|c|}
\hline \multirow{2}{*}{ No } & \multirow{2}{*}{ Regions } & \multicolumn{7}{|c|}{ Indicators } \\
\cline { 3 - 8 } & & $S_{V S}$ & $S_{V A}$ & $S_{D S}$ & $S_{D A}$ & $S_{E S}$ & $S_{E A}$ \\
\hline 1 & Vilnius & 39.8 & $33,919.00$ & 532,827 & 3.77 & 2.70 & $5,978.16$ \\
\hline 2 & Kaunas & 29.6 & $25,248.08$ & $206,284.3$ & 3.04 & 2.15 & $6,148.68$ \\
\hline 3 & Klaipeda & 30.8 & $25,389.98$ & $130,330.3$ & 1.18 & 1.76 & $4,273.07$ \\
\hline 4 & Alytus & 21.5 & $10,868.99$ & $30,291.1$ & 7.97 & 1.67 & $1,778.47$ \\
\hline 5 & Marijampolè & 18.7 & $12,380.47$ & $21,713.1$ & 8.08 & 1.69 & $2,941.59$ \\
\hline 6 & Panevěžys & 24.2 & $16,876.49$ & $61,225.2$ & 1.54 & 2.06 & $3,241.05$ \\
\hline 7 & Šiauliai & 23.6 & $15,168.10$ & 65,502 & 3.09 & 1.72 & $3,226.50$ \\
\hline 8 & Telšiai & 22.1 & $53,222.92$ & $27,291.3$ & 1.19 & 1.60 & $32,849.52$ \\
\hline 9 & Utena & 19.4 & $10,312.49$ & $24,306.5$ & 2.84 & 1.32 & $1,838.72$ \\
\hline 10 & Tauragé & 19.5 & $9,897.75$ & $15,252.9$ & 6.19 & 1.41 & $2,037.76$ \\
\hline
\end{tabular}


Table 4. The results of integrated quantitative assessment of the industrial composition in a region

\begin{tabular}{|c|l|c|c|c|c|c|c|}
\hline \multirow{2}{*}{ No } & \multirow{2}{*}{ Regions } & \multicolumn{7}{|c|}{ Integrated quantitative assessment } \\
\cline { 3 - 8 } & & $S_{V D E}$ & $S_{V S A}$ & $S_{D S A}$ & $S_{E S A}$ & $S_{V D E S}$ & $S_{V D E A}$ \\
\hline 1 & Vilnius & 4.81 & 1.63 & 2 & 1.18 & 3 & 1.81 \\
\hline 2 & Kaunas & 2.68 & 1.22 & 0.47 & 0.98 & 1.94 & 0.74 \\
\hline 3 & Klaipėda & 2.59 & 1.25 & 0.56 & 0.78 & 1.68 & 0.92 \\
\hline 4 & Alytus & 1.50 & 0.75 & 0.08 & 0.67 & 1.22 & 0.28 \\
\hline 5 & Marijampole & 1.49 & 0.71 & 0.06 & 0.72 & 1.14 & 0.34 \\
\hline 6 & Panevėžys & 1.95 & 0.93 & 0.16 & 0.86 & 1.49 & 0.46 \\
\hline 7 & Šiauliai & 1.83 & 0.89 & 0.20 & 0.74 & 1.36 & 0.47 \\
\hline 8 & Telšiai & 3.24 & 1.56 & 0.08 & 1.59 & 1.21 & 2.03 \\
\hline 9 & Utena & 1.29 & 0.69 & 0.05 & 0.55 & 1.03 & 0.26 \\
\hline 10 & Taurage & 1.31 & 0.68 & 0.05 & 0.58 & 1.05 & 0.26 \\
\hline
\end{tabular}

\section{Impact of the industrial composition in the country's regions on the indicators of their economic and social development}

Both the experience of the development in the regions and the sources of literature say that the industry has a material impact on the economic and social development. It is important to present this impact in a quantitative manner so that the overall development process could be managed more efficiently in the regions. We will determine the impact sought using paired and polynomial correlation analysis. In order to carry out such analysis in an integrated manner, the impact that every single indicator of the industrial composition has on the selected indicators of economic and social development in the regions will be assessed, as will be the impact of the indicators of integrated quantitative assessment provided in Table 2 on the mentioned development indicators. The results of the paired correlation analysis carried out in the above manner have been presented in Table 5.

Table 5 enables making a number of important conclusions. First, industrial composition has an immense influence on the key indicators of economic and social development in the regions of the country. This applies to both individual industrial indicators and different combinations thereof. Second, industrial composition in a region has the most influence on foreign direct investment and exports of the goods, followed by unemployment and the gross domestic product. A lesser impact of the industrial composition in a region on unemployment and the gross domestic product is attributable to the fact that they are not only affected by the industry, but also by other components of economic development of the region (construction, transport and agriculture) (Ginevičius, Gedvilaite, \& Bruzgè, 2015).

We will obtain a full view of the impact that the industrial composition has on the economic and social development of a region if we determine, through polynomial correlation analysis, the coefficient of determination that shows the percentage of the impact on the phenomenon subject to examination that is attributable to the indicators included in the model. The results of the calculations have been provided in Table 6 . 
Table 5. The results of the correlation analysis of the impact of industrial composition on the selected indicators of economic and social development in the regions (values of correlation coefficient $r$ )

\begin{tabular}{|l|c|c|c|c|}
\hline \multirow{2}{*}{$\begin{array}{c}\text { Composition of } \\
\text { indicators of the } \\
\text { industrial complex } \\
\text { in the region }\end{array}$} & \multicolumn{3}{|c|}{ Selected indicators of economic and social development in the regions } \\
\cline { 2 - 5 } & $\begin{array}{c}\text { Gross Domestic } \\
\text { Product (GDP) }\end{array}$ & $\begin{array}{c}\text { Foreign Direct } \\
\text { Investment (FDI) }\end{array}$ & $\begin{array}{c}\text { Exports of Goods } \\
\text { of Lithuanian } \\
\text { origin (EG) }\end{array}$ & $\begin{array}{c}\text { Unemployment } \\
\text { (U) }\end{array}$ \\
\hline$S_{V S}$ & 0.574 & 0.757 & 0.899 & -0.651 \\
\hline$S_{S A}$ & 0.799 & 0.991 & 0.950 & -0.879 \\
\hline$S_{D G}$ & 0.557 & 0.751 & 0.897 & -0.653 \\
\hline$S_{D A}$ & 0.299 & 0.965 & 0.788 & -0.515 \\
\hline$S_{V R}$ & 0.600 & 0.848 & 0.939 & -0.833 \\
\hline$S_{V A}$ & 0.640 & 0.941 & 0.980 & -0.662 \\
\hline$S_{V S}+S_{S A}+S_{D G}+$ & 0.711 & 0.956 & 0.925 & -0.615 \\
\hline$S_{D A}+S_{V R}+S_{V A}$ & 0.831 & 0.905 & 0.801 & -0.668 \\
\hline$S_{V S}+S_{S A}$ & 0.442 & 0.810 & 0.916 & -0.687 \\
\hline$S_{D G}+S_{D A}$ & 0.709 & 0.839 & 0.936 & -0.507 \\
\hline$S_{V R}+S_{V A}$ & 0.724 & 0.912 & 0.862 & -0.770 \\
\hline$S_{V S}+S_{D G}+S_{V R}$ & 0.737 & 0.964 & 0.957 & -0.755 \\
\hline$S_{S A}+S_{D A}+S_{V A}$ & & &
\end{tabular}

Table 6. The results of polynomial correlation analysis of the impact of the industrial composition on the selected indicators of economic and social development of the regions (values of the coefficient of determination $\mathrm{R}^{2}$ )

\begin{tabular}{|l|c|c|c|c|}
\hline \multirow{2}{*}{$\begin{array}{c}\text { Composition of } \\
\text { indicators of the } \\
\text { industrial complex } \\
\text { in the region }\end{array}$} & \multicolumn{4}{|c|}{ Selected indicators of economic and social development in the regions } \\
\cline { 2 - 5 } & $\begin{array}{c}\text { Gross Domestic } \\
\text { Product (GDP) }\end{array}$ & $\begin{array}{c}\text { Foreign Direct } \\
\text { Investment (FDI) }\end{array}$ & $\begin{array}{c}\text { Exports of Goods } \\
\text { of Lithuanian } \\
\text { origin (EG) }\end{array}$ & $\begin{array}{c}\text { Unemployment } \\
\text { (U) }\end{array}$ \\
\hline $\begin{array}{l}S_{V S}+S_{S A}+S_{D G}+ \\
S_{D A}+S_{V R}+S_{V A}\end{array}$ & 0.772 & 0.871 & 0.784 & 0.793 \\
\hline$S_{V S}+S_{D G}+S_{V R}$ & 0.273 & 0.054 & 0.248 & 0.566 \\
\hline$S_{S A}+S_{D A}+S_{V A}$ & 0.240 & 0.455 & 0.143 & 0.150 \\
\hline
\end{tabular}

It is evident from Table 6 that the impact of the indicators of industrial composition included in the polynomial model cover 77.2 per cent of the overall impact on the gross domestic product, 87.1 per cent on the foreign direct investment, 78.4 per cent on the exports of the goods and 79.3 per cent on unemployment. This reaffirms that the industrial composition of the region in a country is a material factor to the economic and social development thereof.

It is also evident from the same Table that in the remaining two cases of polynomial correlation, the value of the coefficient of determination is significantly smaller. This leads to a conclusion that, when one measures the industrial composition of a country's region using indicators reflecting only its quantitative side (number, size and number of economic activi- 
ties of the entities) or using indicators reflecting only the qualitative side of the activities, i.e. turnover, the view that is obtained is not full. In order to assess the industrial composition in an adequate manner, both aspects have to be combined into a harmonised system of indicators as it has been done in the proposed methodology.

There is a question regarding the proposed versatility of the methodology for quantifying the regional industry composition, i.e., whether the scope of its application depends on the size of the region. It's basically a problem with getting information. If statistical information bases present it at the regional level, as is in Lithuania, Poland and other similar countries, the size of the country's region is not an obstacle to the proposed methodology.

\section{Conclusions}

The industrial composition of the country's region is proposed to be measured using indicators that reflect three key aspects: the variety by the economic entities that are active, by their size and by the types of their economic activities. Each and every aspect is defined by two indicators: the first one being the number of undertakings and their turnover per one thousand inhabitants of the region; the second one being the groups of the number of employees and the turnover of such groups per one thousand inhabitants of the region; and the third one being the number of economic activities and their turnover per one thousand inhabitants of the region.

The paired correlation analysis of the impact of the industrial composition in the Lithuanian regions on the indicators of economic and social development has demonstrated that, first, the industrial composition presented through both individual industrial indicators and different combinations thereof has an immense influence on the key indicators of economic and social development of the country's regions, i.e. the gross domestic product, foreign direct investment, exports of the goods and unemployment; secondly, the industrial composition in a region has the most effect on foreign direct investment and the exports of the goods and a lesser impact on unemployment and gross domestic product.

The impact of the proposed system of indicators of industrial composition in a country's region covers 77.2 per cent of the overall impact on the gross domestic product; 87.1 per cent impact on the foreign direct investment; 78.4 per cent impact on the exports of the goods and 79.3 per cent impact on unemployment. This fact demonstrates that the proposed system of indicators of the industrial composition is suitable for examining its impact on the sustainable development of the country's regions.

\section{References}

Anderson, K. (1995). Australia's changing trade pattern and growth performance. In R. Pomfret (Ed.), Australia's trade policies. Melbourne: Oxford University Press.

Balassa, B. (1965). Trade liberalisation and revealed comparative advantage. Manchester: the Manchester School of Economic and Social Studies.

Bernatonyte, D., \& Normandiene, A. (2009). Estimation of trade specialization: the case of the Baltic States. Engineering Economics, 2, 7-17. 
Boggia, A., \& Cortina, C. (2010). Measuring sustainable development using a multi-criteria model: a case study. Journal of Environmental Management, 91, 2301-2306. https://doi.org/10.1016/j.jenvman.2010.06.009

Bradbury, K., \& Kodrycki, Y. K. (2007). Massachusetts employment growth 1996-2006: effects of industry performance and industry composition. Research Review, 7, 24-25.

Brunner, H. P., \& Cali, M. (2005). Dynamics of manufacturing competitiveness in south Asia: analysis through export data (ERD Working Paper No. 77). Asian Development Bank.

Capasso, M., Stam, E., \& Cefis, E. (2015). Industrial dynamics and economic geography. Regional Studies, 49(1), 5-9.

Carlton, D., \& Perloff, J. M. (1994). Modern industrial organization. New York: Harper Collins College Publishers.

Chow, P. C. Y., \& Kellman, M. H. (1993). Trade - the engine of growth in East Asia. New York: Oxford University Press. https://doi.org/10.1093/acprof:oso/9780195078954.001.0001

Lietuvos statistikos departamentas. (2014). Lietuvos apskritys skaičiais / Counties of Lithuania in Figures 2013. Retrieved from https://osp.stat.gov.lt/services-portlet/pub-edition-file?id=2908

Čiučkovič, N., Jurlin, K., \& Vučkovič, V. (2013). Measuring regional competitiveness: the case of Croatia. Southeast European and Blach Sea Studies, 13(4), 503-523. https://doi.org/10.1080/14683857.2013.859813

Drysdale, P. (1988). International economic pluralism. Sydney: Allen \& Unwin.

Duman, G. M., Tozanli, O., Kongar, E., \& Gupta, S. M. (2017). A holistic approach for performance evaluation using quantitative and qualitative data: a food industry case study. Expert Systems with Applications, 81, 410-422. https://doi.org/10.1016/j.eswa.2017.03.070

Dumčiuvienè, D. (2001). Rinkos struktūros - i̇monès elgsenos - veiklos rodikliu paradigma alaus pramonès pavyzdžiu [Market structure - the company's behavior - performance paradigm example of the beer industry]. Engineering Economics, 1, 15-19.

Garnaut, R. (1989). Australia and the Northeast Asian ascendancy. Canberra: Australian Government Publishing Service.

Ginevičius, R., Gedvilaite, D., \& Bruzgè, Š. (2015). Assessment of a country's regional economic development on the basis of Estimation of a Single Process (ESP) method. Entrepreneurial Business and Economics Review, 3(2), 141-153. https://doi.org/10.15678/EBER.2015.030210

Ginevičius, R., \& Podvezko, V. (2008). A feasibility study of multicriteria methods' application to quantitative evaluation of social phenomena. Business: Theory and Practice, 9(2), 81-87.

Grasmik, K. (2015). Alternative assessment of volume and industry structure of foreign direct investment in Russia. Studies on Russian Economic Development, 26(3), 218-224.

https://doi.org/10.1134/S1075700715030065

Hallack, J. C. (2004). Product quality, linder and the direction of trade. University of Michigan. Retrieved from http://www.ekf.vsb.cz/export/sites/ekf/projekty/cs/weby/esf-0116/databaze-prispevku/ ersa_2012/ersa_2012_00788.pdf. https://doi.org/10.3386/w10877

Hongxia, C., \& Guoping, L. (2011). Empirical study on effect of industrial structure change on regional economic growth of Beijing-Tianjin-Hebei Metropolitan Region. Chinese Geographical Science, 21(6), 708-714. https://doi.org/10.1007/s11769-011-0478-9

Hwang, C., \& Yoon, K. (1981). Multiple attribute decision making - methods and applications. A state of the art survey. New York, Berlin, Heidelberg: Springer Verlag. https://doi.org/10.1007/978-3-642-48318-9

Janissen, B., Thomson, R., Clark, C., \& Geer, T. (1998). Aspects of structural change in Australia. In Productivity Commission: Research Paper. Commonwealth of Australia. 
Karabaga, S. F., \& Berggren, C. (2014). Antecedents of firm performance in emerging economies: Business groups, strategy, industry structure, and state support. Journal of Business Research, 67(10), 2212-2223. https://doi.org/10.1016/j.jbusres.2014.01.004

Kondyli, J. (2010). Measurement and evaluation of sustainable development. A composite indicator for the islands of the North Aegean region, Greece. Environmental Impact Assessment Review, 30, 347-356. https://doi.org/10.1016/j.eiar.2009.08.006

Kozubikova, L., Homolka, L., \& Kristalas, D. (2017). The effect of business environment and entrepreneurs' gender on perception of financial risk in the SME's sector. Journal of Competitiveness, 9(1), 36-50. https://doi.org/10.7441/joc.2017.01.03

Misra, A. (2006). Growth and structural change in manufacturing industries since 1980-1981 to 20012002. Journal of Industrial Economics, 1, 71-76.

Rajnoha, R., \& Lesníková, P. (2016). Strategic performance management system and corporate sustainability concept - specific parametres in Slovak enterprises. Journal of Competitiveness, 8(3), 107-124. https://doi.org/10.7441/joc.2016.03.07

Saboniene, A. (2009). Lithuanian export competitiveness: comparison with other Baltic States. Engineering Economics, 2, 49-57.

Saboniene, A. (2010). The evaluation of the potencial of Lithuanian manufacturing industry structure on the basis of CI Index. Engineering Economics, 21(4), 399-407.

Sheehan, P. J. (2000). Manufacturing and growth in the longer term: an economic perspective (CSES Working paper No. 17). Melbourne: Victoria University.

Sheehan, P. J., \& Tikhomirova, G. (1996). Diverse paths to industrial development in East Asia and ASEAN (CSES Working paper No. 6). Melbourne: Victoria University.

Silva, R., \& Ferreira-Lopes, A. (2014). A Regional development index for Portugal. Social Indicators Research, 118(3), 1055-1085. https://doi.org/10.1007/s11205-013-0455-Z

Snieška, V., \& Bruneckiene, J. (2009). Measurement of Lithuanian Regions by regional competitiveness index. Engineering Economics, 1, 45-57.

Szirmai, A., Ruoen, R., \& Bai, M. (2005). Chinese manufacturing performance in comparative perspective, 1980-2002 (Economic Growth Center Discussion paper No. 920). Economic Growth Center: Yale University.

Tikhomirova, G. (1997). Analysing changes in industry structure (CSES Working paper No. 11). Melbourne: Victoria University.

Wu, H. F., \& Tam, T. (2015). Economic development and socioeconomic inequality of well-being: a cross-sectional time-series analysis of urban China, 2003-2011. Social Indicators Research, 124(2), 401-425. https://doi.org/10.1007/s11205-014-0803-7 